\title{
Study of Various Techniques for Improving Weak and Compressible Clay Soil under a High Earth Embankment
}

\author{
A.K. M. Zein ${ }^{1}$ and L. E. Elgasim ${ }^{2}$ \\ ${ }^{1}$ University of Khartoum, Building and Road Research Institute, Khartoum, Sudan \\ ${ }^{2}$ University of Khartoum, Faculty of Engineering, Khartoum, Sudan
}

\begin{abstract}
This paper investigates the suitability of three soil improvement techniques for the construction of a high earth embankment on thick weak and highly compressible clay soil. The eastern approach embankment of Alhalfaya Bridge on the River Nile linking Khartoum North and Omdurman cities was chosen as a case study and a comprehensive site investigation program was carried out to determine the properties the subsurface soils. The study results showed that unless the subsurface soils have been improved they may fail or undergo excessively large settlements due to the embankment construction. Three ground improvement techniques based on the principles of the "staged construction method, SCM", "vertical sand drain, VSD" and "sand compaction piles, SCP" of embankment foundation soil treatment are discussed and evaluated. Embankment design options based on applications of the above methods have been proposed for foundation treatment to adequately support embankment loads. A method performance evaluation based on the improvement of soil properties achieved; the time required for construction and compared estimated costs criteria was made to assess the effectiveness and expected overall performance. Adoption of any of the soil improvement techniques considered depends mainly on the most critical and decisive factor governing the embankment design. Based on the overall performance for the embankment case studied, the sand drains is considered as the most appropriate improvement method followed by the sand compaction piles technique whereas the staged construction method showed the poorest overall performance.
\end{abstract}

\section{Introduction}

The design and construction of high embankments placed on weak and compressible soils i.e. low shear strength and excessively large settlements pose several problems with respect to their safety and stability. This has lead to the development of ground improvement techniques for overcoming such instability problems. The main geotechnical aspects that should normally be considered for such soil conditions include the settlement and bearing capacity of foundation soils and the stability of embankment. The soil settlement typically consists of three components; immediate, primary and secondary. The primary settlement is due to compression of the soil resulting from the gradual escape of water from the voids of loaded soil and accounts for the majority of the total settlement.

The stability of an embankment built on highly compressible soils can be evaluated by determining the soil shear strength of the embankment and foundation soil strata using the Terzaghi's bearing capacity. Foundation soils can provide adequate support for overlying embankments if the imposed stresses do not exceed their shear strength. Overstressing the embankment or foundation soil may result in embankment slope failures.

In Sudan, most the approach road embankments leading major bridge projects built across River Nile or its main tributaries must be constructed at relatively large heights on weak alluvial deposits that need to be improved. Various ground improving methods such as the surcharge loading, stone columns, wick drains, sand compaction piles and geo-synthetic reinforcement, have been used in various countries to accelerate settlement and enhance embankment stability issues associated with embankment construction on weak soils.

This study investigates the suitability of three soil improvement techniques for the design of a high approach embankment on thick weak and compressible clay soil deposits. Embankment design solutions based on the principles of the "staged construction method, SCM", "vertical sand drain, VSD" and "sand compaction piles, SCP" techniques for the treatment of the natural weak foundations soils are discussed and evaluated in this paper. 


\section{Description of the case study considered}

The embankment site chosen for study was the location of the eastern abutment of Alhalfaya Bridge built across River Nile to link Omdurman city and Khartoum North town in Khartoum State, Sudan. The embankment is of the rolled earth type with a maximum height of $12.0 \mathrm{~m}$. $30 \mathrm{~m}$ top width and $78 \mathrm{~m}$ bottom width with $1: 2$ (vertical: horizontal) side slopes.

A site investigation program comprised of borehole drilling, cone penetration tests (CPT) soundings and laboratory tests was carried out to determine the required properties the subsurface soils. Typical soil profiles, SPT and CPT plots with depth of the investigated embankment site are illustrated in figures 1 and 2.

\begin{tabular}{|c|c|}
\hline $\begin{array}{c}\text { Depth } \\
(\mathrm{m})\end{array}$ & $\begin{array}{c}\text { Soil Types } \\
\text { and groups }\end{array}$ \\
\hline $0-3$ & $\begin{array}{l}\text { Silty Clay, } \\
\text { CL }\end{array}$ \\
\hline $3-4$ & $\begin{array}{c}\text { Clayey silt, } \\
\text { ML }\end{array}$ \\
\hline $4-5$ & Silty clay, CL \\
\hline $5-6$ & $\begin{array}{c}\text { Clayey silty } \\
\text { sand, SM }\end{array}$ \\
\hline $6-9$ & $\begin{array}{c}\text { Silty sand, SP } \\
\text { Fine sand } \\
\text { with little } \\
\text { gravel, SP }\end{array}$ \\
\hline $13-14$ & $\begin{array}{c}\text { weathered } \\
\text { Sandstone }\end{array}$ \\
\hline
\end{tabular}

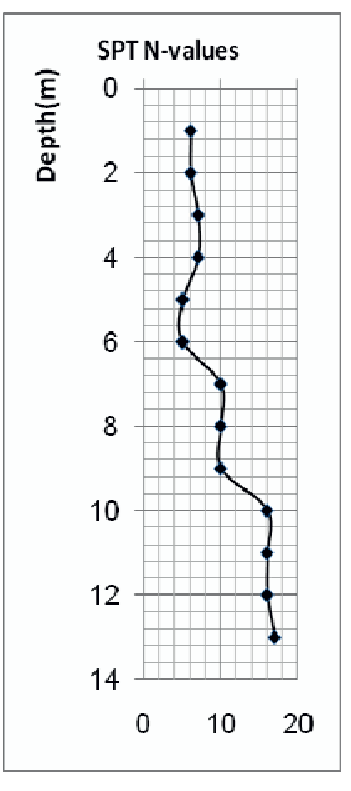

Fig. 1 Typical profiles of soil types and SPT results

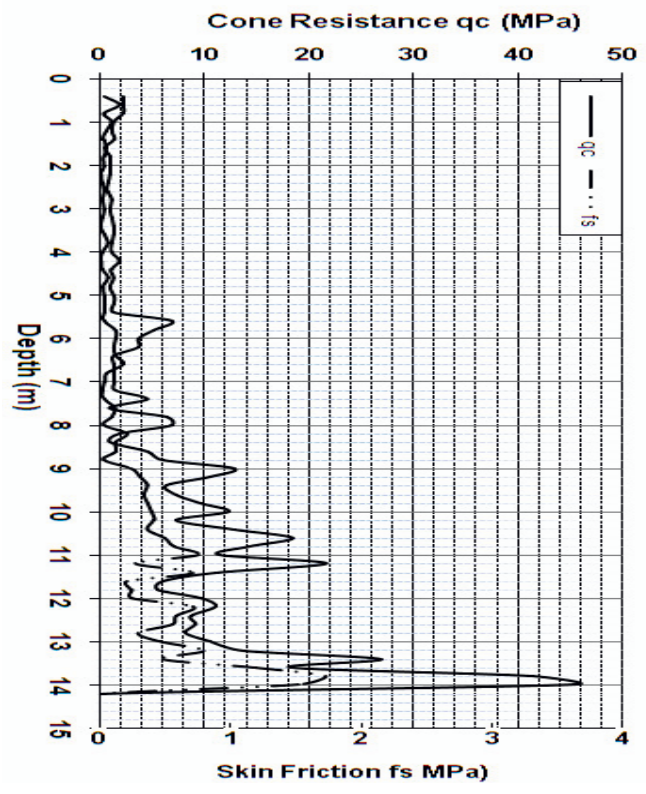

Fig. 2 Typical CPT profile in study site
As may be noted in these figures, the soil profile comprised of a soft silty clay soil layer ranging in depth from $1.0 \mathrm{~m}$ to $6.0 \mathrm{~m}$, underlain by a very loose to medium dense poorly graded fine to medium coarse silty sand or sandy silts extending to a depth of $14.0 \mathrm{~m}$. These alluvial deposits rest directly on the highly weathered sandstone formation. The natural moisture content varied from $26 \%$ to $42 \%$ with most values between 28 and $32 \%$. The natural dry density ranged between 11.0 and $14.5 \mathrm{kN} / \mathrm{m}^{3}$.

The total settlement of clay soil was computed from the results of consolidation tests performed on representative undisturbed soil samples and a value of $874 \mathrm{~mm}$ was obtained for the profile representing the worst subsurface conditions. The settlement component due to primary consolidation was found to constitute from 75 to $90 \%$ of the total computed soil settlements with an average value of $690 \mathrm{~mm}$. The coefficient of consolidation $\mathrm{c}_{\mathrm{v}}$ was estimated using the rate of settlement and was found to vary from 4.3 to $5.2 \mathrm{~m}^{2} /$ year. Based on these values, the time required to reach $90 \%$ of the total settlement was found to vary considerably from 1.2 to 9.5 years.

The results obtained from the SPT, CPT and UCS laboratory tests were used to estimate the shear strength parameters and the bearing capacity of the embankment foundation soils. The undrained cohesion of the clay layer was in the range of 45 to $55 \mathrm{kPa}$ with an average value of $50 \mathrm{kPa}$. The allowable bearing capacity of the clay soil layer was estimated to be 150 to $170 \mathrm{kPa}$.

Based on analysis of the investigation results it was obvious that the subsurface soil conditions prevailing at study site will not be capable to support the loads imposed by the high embankment adequately. Therefore, the upper weak and highly compressible clay soil stratum should be treated before embankment construction using ground improvement techniques.

Various ground improvement techniques are currently available and have successfully been applied to increase shear strength and reduce compressibility characteristics of weak and compressible soils. Choice of any of them depends among several factors on the geological formation of the soil, soil characteristics, cost and experience. The analytical study undertaken to investigate the effectiveness and suitability of three selected techniques for improving of the embankment foundation soils is described in the following section.

\section{Improvement methods considered for weak clay soils treatment}

\subsection{Staged construction method (SCM)}

The low strength and compressible nature of the subsoil clay strata warrant special precaution to be taken in order to avoid failure during to construction in case a single stage construction option is adopted. Construction over soft clays can only be done in single stage safely for high embankments with very flat slopes or having berms on slopes which renders it to be 
uneconomical with respect to land and earthwork. Such a problem may be overcome by applying the stage construction method. This technique is mainly employed as a means of gradually increasing the shear strength of soft clay soils which would otherwise be inadequate to carry the embankment load safely. Consideration is given to the advantage of shear strength increase in of sub-soil strata due to consolidation by surcharge of embankment loading. The principle of the stage construction method is shown in figure 3 below.

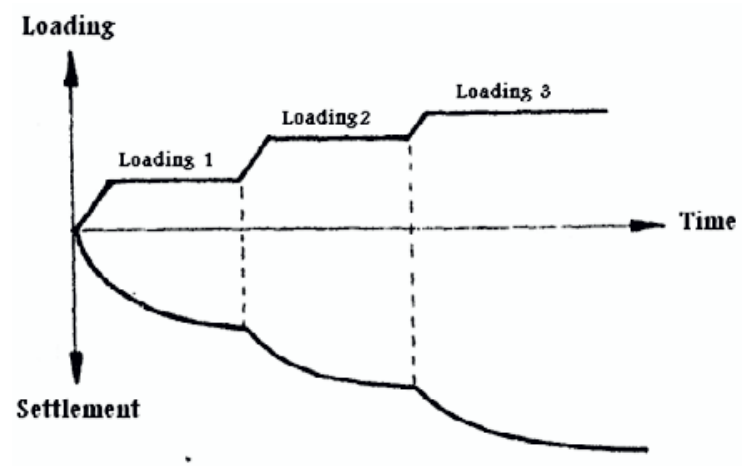

Fig. 3 Principle of staged construction method

To investigate the possibility of applying this method for improving the foundation soils under the embankment considered, the following fill material and subsoil parameters and assumptions were made:

- Embankment fill material having saturated unit weight of $20 \mathrm{kN} / \mathrm{m}^{3}$, angle of internal friction of $\varphi=$ $35^{\circ}$ and cohesion $\mathrm{c}=0$.

- Compressible cohesive soil layer of average thickness $5 \mathrm{~m}$, submerged unit weight $\gamma_{\text {sub }} 7 \mathrm{kN} / \mathrm{m}^{3}$, average cohesion of subsoil $c_{u}$ of $50 \mathrm{kN} / \mathrm{m}^{2}$, angle of shearing resistance $\varphi$ of $6^{\circ}$ and average coefficient of consolidation $\mathrm{C}_{\mathrm{v}}=4.80 \mathrm{~m}^{2} /$ year.

The staged construction design procedure described by the Ministry of Railways in India [1] was followed to achieve a $90 \%$ degree of the primary consolidation through construction of the embankment in three successive phases with 6 months waiting times after the first and the second stages. An intermediate drain path (i.e. between single and double drainage conditions) was assumed as the bottom layer is semi-impervious. The factor of safety (FS) for embankment stability is correlated to $\mathrm{D} / \mathrm{H}$ (clay layer thickness to embankment height ratio) for different $\varphi$ (friction angle of the fill) and a stability $\mathrm{N}$ number given by $\left(\mathrm{c}_{\mathrm{u}} / \gamma \mathrm{H}\right)$. The stability of the $12 \mathrm{~m}$ high embankment was analysed assuming construction gradually in $6.0 \mathrm{~m}, 4.5 \mathrm{~m}$ and $1.5 \mathrm{~m}$ in the $1^{\text {st }}, 2^{\text {nd }}$ and $3^{\text {rd }}$ stages respectively using the design charts developed by Sanglerat et al [2]. A minimum FS value of 1.20 is required for embankment stability according to this design method.

Evaluation of the degree of improvement attained in the clay foundation stratum using staged construction method showed that:

a) Allowing 6 months waiting period after the $1^{\text {st }}$ loading stage produced an increase in the undrained shear strength of about $9 \%$ and a consolidation degree of $35 \%$ in the clay layer. The factor of safety for embankment stability was found to be $2.18(>1.20)$.

b) Allowing 6 months waiting time after the $2^{\text {nd }}$ loading stage resulted in an increase of about $20 \%$ in the undrained shear strength and gave a consolidation degree of about $50 \%$ and $35 \%$ after the $1^{\text {st }}$ and $2^{\text {nd }}$ construction stages respectively due to the added embankment height of $4.5 \mathrm{~m}$. The embankment factor of safety for embankment stability was found to be 1.49 .

\subsection{Vertical sand drains (VSD)}

The use of vertical sand drains in soft clay accelerate the primary consolidation of clay since they bring about rapid dissipation of excess pore water pressure under embankment loading. Vertical drains are normally used where preloading alone will not be efficient. The installation of sand drains into relatively thick clay strata increases the rate of consolidation of the clay under the load by shortening the drainage path. The advantages of this method include; (a) The increased rate of gain in shear strength of clay enables the load to be applied more rapidly than would otherwise have been possible (b) The increasing rate of consolidation of the clay results in a reduction of the time required for the primary consolidation settlement; thus the structures or embankments can be put to use earlier than it would be possible otherwise

The design of any sand drain project involves the determination of drain spacing which will give the required degree of consolidation in specified period of time. Such drains are usually installed in triangular or square grid pattern with spacing ranging from $1 \mathrm{~m}$ to 4 $\mathrm{m}$. The spacing is generally fixed depending upon the loading conditions of embankment and soft subsoil characteristics. The depth of treatment is often taken as the full depth of soft or impermeable soils. Barron [3] proposed a solution for radial consolidation by based on Terzaghi's three dimensional consolidation equations whereby the overall drainage is the summation of the vertical and radial drainages. The design of sand drains can be done knowing the coefficient of consolidation, preloading time period, target degree of consolidation and drain diameter.

An analytical method of sand drains design based on the above solution was applied using the data and information gathered for the subsurface soils and the embankment at the study site considered. Drains with 0.20 to $0.40 \mathrm{~m}$ diameters arranged in square and triangular grid patterns were assumed to achieve a target consolidation degree of $90 \%$ after waiting (loading) time durations of 6, 8 and 10 months. Double drainage was assumed in the analysis considering that the drains are extended to reach the pervious sand layer underlying the compressible soil. A summary of the sand drain design options expressed in terms of the required spacing $(\mathrm{m})$ is given in Table 1 for assumed drain diameters, construction time durations and piles arrangement patterns. 
Table 1 Summary of vertical sand drain design options for foundation soil improvement

\begin{tabular}{|c|c|c|c|c|c|c|c|}
\hline \multicolumn{2}{|c|}{ Waiting Time } & \multicolumn{2}{|c|}{$\begin{array}{c}6 \\
\text { Months }\end{array}$} & \multicolumn{2}{|c|}{$\begin{array}{c}8 \\
\text { Months }\end{array}$} & \multicolumn{2}{|c|}{$\begin{array}{c}10 \\
\text { Months }\end{array}$} \\
\hline \multicolumn{2}{|c|}{ Grid pattern } & Sq. & $\mathrm{Tr}$ & Sq. & Tr. & Sq. & Tr. \\
\hline \multirow{5}{*}{$\begin{array}{l}\text { drains } \\
\text { diam. } \\
\text { (m) }\end{array}$} & 0.20 & 2.6 & 2.8 & - & - & 3.6 & 3.9 \\
\hline & 0.25 & - & - & 3.2 & 3.4 & - & - \\
\hline & 0.30 & 2.8 & 3.0 & - & - & 3.9 & 4.2 \\
\hline & 0.35 & - & - & 3.3 & 3.5 & - & - \\
\hline & 0.40 & - & - & 3.6 & 3.8 & - & - \\
\hline
\end{tabular}

Based on the data in Table 1, the most feasible design options for all drain diameters would be those of the triangular grid patterns having diameter/spacing of $0.20 \mathrm{~m} / 2.8 \mathrm{~m}$ for 6 months, $0.25 \mathrm{~m} / 3.0 \mathrm{~m}$ for 8 months and $0.30 \mathrm{~m} / 4.0 \mathrm{~m}$ for 10 months waiting times. The sand drain design option with $0.20 \mathrm{~m}$ diameter and $2.80 \mathrm{~m}$ spacing represents the most viable since it requires the shortest waiting time duration.

A graphical solution published by Terrasol and cited by Kirmani [4] was also used for the case study under consideration to compare with the analytical sand drain design of. For the same drain diameters, the graphical method gave more conservative design (i.e. closer drain spacings) than those obtained in the analytical method by $25 \%$ to $33 \%$ for the square and triangular grid patterns respectively.

\subsection{Sand compaction piles (SCP)}

The sand compaction piles (SCP) is a forced replacement improvement technique in a soft soil which has been developed and applied in Japan since 1966 [5] to improve stability and/or reduce compressibility of cohesive soils. Sand is fed through a casing pipe into the ground and compacted either by vibration, dynamic impact or static excitation to construct a compacted sand pile. Figure 4 shows the principle of the SCP improvement method in which the replacement ratio $a_{s}$ is defined in terms of the soil void ratio as:

$$
a_{s}=\Delta e /\left(\left(1+e_{0}\right)\right.
$$

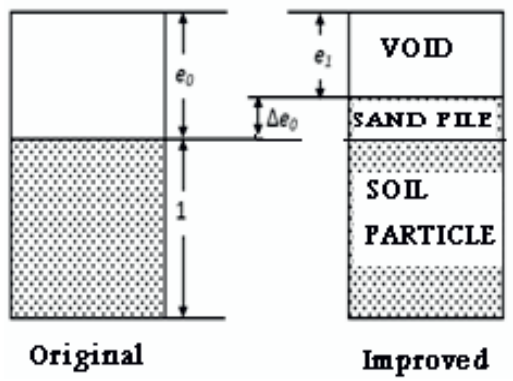

Fig. 4 Principle sand compaction piles method
Sand amounting to a change in void ratio $\Delta e$ from original value $\mathrm{e}_{0}$ to final value $\mathrm{e}_{1}$ is introduced into the original ground of volume represented by $\left(1+\mathrm{e}_{0}\right)$.

A sand compaction piles (SCP) design method based on "area replacement ratio" concept [5] was applied to improve the strength and compressibility properties of the cohesive soil prevailing at the study site. In this method, the area replacement ratio $\left(a_{\mathrm{s}}\right)$ is defined as the ratio of the granular pile area $\left(\mathrm{A}_{\mathrm{s}}\right)$ over the whole area of the equivalent cylindrical unit within the cell $\left(A_{s}+A_{c}\right)$, where $A_{s}$ is the horizontal area of a granular pile and $A_{c}$ is the horizontal area of the clayey ground surrounding the piles. The $a_{s}$ value can be calculated for given diameter and spacing of sand piles using different equations for the square and triangular arrangement patterns. For sand piles of $1.0 \mathrm{~m}$ diameter with 2.0 and $2.5 \mathrm{~m}$ spacing, the corresponding $\mathrm{a}_{\mathrm{s}}$ values will be 0.197 and 0.126 for the square pattern and 0.227 and 0.145 for the triangular pattern of sand piles spaced at $2.0 \mathrm{~m}$ and $2.5 \mathrm{~m}$ respectively.

The bearing capacity of ground improved by the SCP method is often evaluated using the Terzaghi's theory. The bearing capacity values of uniform clay $\left(\mathrm{q}_{\mathrm{as}}\right)$ and uniform sand $\left(\mathrm{q}_{\mathrm{as}}\right)$ are first calculated individually then the bearing capacity of SCP improved ground $\left(\mathrm{q}_{\mathrm{a}}\right)$ is calculated by the weighted average of the bearing capacities of all piles using the replacement area ratio, $\mathrm{a}_{\mathrm{s}}$ according to:

$$
q_{a}=\left[a_{s} * q_{a s}+\left(1-a_{s}\right) * q_{a c}\right.
$$

The bearing capacities of clay ground $\left(\mathrm{q}_{\mathrm{ac}}\right)$ and pile sand soils $\left(\mathrm{q}_{\mathrm{as}}\right)$ are given by:

$$
\begin{aligned}
q_{a c} & =\left(c * N_{c} / F S\right) \\
q_{a s} & =\left(0.5 * B * \gamma_{s} * N \gamma / F S\right)
\end{aligned}
$$

Where $\mathrm{c}$ is the clay soil cohesion, $\mathrm{N}_{\mathrm{c}}$ and $\mathrm{N}_{\gamma}$ are the bearing capacity factors, $B$ is the foundation width, $\gamma_{s}$ is the sand soil unit weight and FS is the factor of safety against shear failure. The input data soil required for applying this method were derived and used for the computations of the allowable bearing capacity of the SCP improved soil strata. A summary of the allowable bearing capacities for pile sand materials with various values of internal friction angle is presented in Table 2.

Table 2 Estimated allowable bearing capacity of improved foundation soil $\left(\mathrm{kN} / \mathrm{m}^{2}\right)$

\begin{tabular}{|c|c|c|c|c|c|}
\hline \multicolumn{2}{|c|}{$\begin{array}{c}\text { Sand soil } \\
\text { properties }\end{array}$} & \multicolumn{2}{c|}{$\begin{array}{c}\text { Triangular pattern } \\
\text { at spacing of }\end{array}$} & \multicolumn{2}{c|}{$\begin{array}{c}\text { Square pattern } \\
\text { at spacing of }\end{array}$} \\
\hline$\varphi$ & $\mathrm{N} \gamma$ & $2.0 \mathrm{~m}$ & $2.5 \mathrm{~m}$ & $2.0 \mathrm{~m}$ & $2.5 \mathrm{~m}$ \\
\hline 33 & 35 & 199 & 196 & 193 & 191 \\
\hline 34 & 41 & 213 & 207 & 205 & 200 \\
\hline 35 & 48 & 228 & 219 & 219 & 211 \\
\hline 36 & 57 & 249 & 235 & 235 & 224 \\
\hline
\end{tabular}

The reduction in the primary consolidation settlement of improved ground may be calculated by 
multiplying the final consolidation settlement of the original ground before improvement by a reduction factor, $\beta$ related to the stress ratio (n) the area replacement ratio $\left(a_{\mathrm{s}}\right)$ as follows:

$$
\beta=\left(1+\left(n-a_{s}\right)\right)-1
$$

A stress ratio $n$ value of 5 was assumed for computing the settlement reduction factor $\beta$ for soils treated with sand piles of $1.0 \mathrm{~m}$ diameter and different spacing and arrangement patterns in the considered case study using the above equation and a summary the values obtained is given in Table 3 .

Table 3 Values of settlement reduction factor $(\beta)$

\begin{tabular}{|l|c|c|c|c|}
\hline Pile grid pattern & \multicolumn{2}{|c|}{ Triangular } & \multicolumn{2}{c|}{ Square } \\
\hline $\begin{array}{l}\text { Sand pile pacing } \\
(\mathrm{m})\end{array}$ & 2 & 2.5 & 2 & 2.5 \\
\hline $\begin{array}{l}\text { Area replacement } \\
\text { ratio }\left(\mathrm{a}_{\mathrm{s}}\right)\end{array}$ & 0.227 & 0.145 & 0.197 & 0.126 \\
\hline $\begin{array}{l}\text { Settlement } \\
\text { reduction factor }(\beta)\end{array}$ & 0.524 & 0.632 & 0.560 & 0.665 \\
\hline
\end{tabular}

Based on evaluation of the results given in Tables 2 and 3 for the treated clay soils it is obvious that the most appropriate design is to use $1.0 \mathrm{~m}$ diameter sand piles distributed in a triangular pattern at spacing of $2.0 \mathrm{~m}$ and the sand piles should be compacted to achieve a minimum internal friction angle of $34^{\circ}$.

\section{Comparison and general evaluation of soil improvement methods}

\subsection{Effectiveness of soil improvement methods}

Based on the findings of this study an assessment of the success and effectiveness of the ground improvement techniques to attain an acceptable embankment design was made for the case study under consideration. The discussion is focused on the main ground improvement design issues which include settlement reduction, gain in shear strength, shortening of construction time and cost effectiveness.

\subsubsection{Reduction of consolidation settlement}

As stated in section 2, excessively large total settlements are anticipated to take place in the compressible soils due to the placement of the high embankment if they have not been improved. A very long time (43 months) would be required to reach $90 \%$ settlement in untreated foundation soils. The magnitudes and rate of estimated settlements computed in this study were considered unacceptable and therefore measures should be taken to expedite this process. In practice, it is generally desirable that the compressible soils underlying bridge abutments reach $90 \%$ consolidation within a year.
In the staged construction method, the degree of settlement achieved in the clay soil layer before the application of the 3rd stage loading was about $85 \%$ which is approaching $90 \%$ value normally targeted in the application of soil improvement techniques. Similarly, installation of sand drain prior to embankment construction is expected to result in a $90 \%$ degree of the primary consolidation settlement. On the other hand, reinforcing the embankment foundation soils by sand compaction piles is expected to produce only $48 \%$ reduction in the anticipated primary consolidation settlement of the untreated soils.

\subsubsection{Gain in soil shear strength}

The natural upper cohesive soil in the investigated site has low shear strength and an estimated allowable bearing capacity of 150 to $170 \mathrm{kPa}$ which is much lower than the pressures expected to be imposed by embankment weight $(\sim 220 \mathrm{kPa})$. Construction of a high embankment on such soils necessitates using gentle side slopes and/or berms in the embankment section which involves very large volumes of fill and considerable delays in the construction time schedule which renders the project to be not feasible.

The gain in the bearing capcity of the clay soil due to the staged construction method was estimated to be about $20 \%$ of the untreated clay soil after the 2 nd construction phase. Application of the sand drain design is expected to produce an improvement of about $40 \%$ in the bearing capacity of the treated cohesive foundation soil. It is expected that the shear strength and thus the allowable bearing capacity of the clay soil will be increased by $35 \%$ as a result of improvement by the sand compaction piles method.

\subsubsection{Time required for construction}

As previously stated, a very long time (3.56 years) would be required to reach $90 \%$ degree of consolidation if the embankment is constructed in a single stage on the unimproved foundation soils.

Using staged construction method, the embankment construction can be accomplished in about 1.25 to 1.50 years including material filling and waiting time after the two main construction phases. In the sand drain method, assuming that 4.5 months would be required for sand drains installation and fill material placement then the approximate duration needed for embankment construction will be between 10.5 and 14.5 months. The time required for soil improvement by the SCP technique is dependent on availability of the appropriate plant and experienced contractor who can execute the works. In case such facilities and requirements are secured, then the construction could be completed within a time much shorter than that required for sand drain method. For comparison, this time was estimated to be about 8 months. 


\subsubsection{Rough comparison of improvement method costs}

Cost effectiveness is essential for selecting the most suitable embankment foundation soils treatment method. The total cost of the project considered in this study is governed by many factors such as the size of the job, costs of construction materials, machinery and plants and work force. It will be extremely difficult to estimate the overall cost for the application of improvement techniques to be considered in the specific case studied. In this study, only a rough costing comparison was assumed for each of the improvement methods considered to evaluate their performance.

Staged construction does not require importing foreign construction material or using expensive plants (such as drilling rigs and heavy compaction machines) as opposed to the other two methods and therefore it will the most cost effective method. Generally, the types of materials and equipment used for installation of sand drain and sand piles resemble each other but may considerably differ in the amounts and quality of replacement sand material used and the sizes and technical specifications of plant required. Considering these differences, an assumption was made herein such that the costs of the sand drain and sand compaction methods exceed that of the staged construction method by 25 and $50 \%$ respectively.

\subsection{General evaluation of soil improvement method performance}

A simple analysis approach was adopted for the evaluation of the three improvement methods with respect to their effectiveness and expected embankment performance based on the design options proposed for subsurface soil treatment. The following criteria were used for the ranking the expected overall performance of the three improvement techniques:

- $\quad$ The degree of improvement in soil properties of treated soil (namely the reduction in total settlement and gain in the shear strength).

- $\quad$ The time required for construction, and

- Comparisons of embankment construction cost

Each of the above criteria may be evaluated and expressed in terms of ranking indices (R1 to R4) reflecting the discrepancy from the best (most desirable) result scored by a given design method. For example, the best performance for the settlement reduction criterion obtained in the sand drain method $(90 \%)$ is taken as a datum for computing absolute deviations (in percentage) of the reductions in the other two methods and so forth. An overall ranking index (R), defined as the sum of single indices shall be used to quantitatively evaluate the performance of each method. According to this evaluation criterion, the lower the ranking index the better would be the performance of the method and vice versa. A summary of the overall performance data pertaining to the improvement methods ranking according to the above criteria is given in Table 4.
Table 4 Ranking of the soil improvement methods

\begin{tabular}{|l|c|c|c|c|}
\hline \multicolumn{2}{|l|}{$\begin{array}{l}\text { Design method and } \\
\text { Evaluation criteria }\end{array}$} & SCM & VSD & SCP \\
\hline $\begin{array}{l}\text { Settlement } \\
\text { reductions }\end{array}$ & $\%$ & 85 & 90 & 48 \\
\cline { 2 - 5 } & $\mathrm{R} 1$ & 6 & 0 & 47 \\
\hline $\begin{array}{l}\text { Shear strength } \\
\text { gains }\end{array}$ & $\%$ & 20 & 40 & 35 \\
\cline { 2 - 5 } $\begin{array}{l}\text { Construction } \\
\text { times }\end{array}$ & $\mathrm{R} 2$ & 50 & 0 & 13 \\
\cline { 2 - 5 } & $\mathrm{R} 3$ & 1.38 & 0.88 & 0.67 \\
\hline $\begin{array}{l}\text { Comparable } \\
\text { costs }\end{array}$ & $\%$ & 100 & 31 & 0 \\
\cline { 2 - 5 } & $\mathrm{R} 4$ & 0 & 25 & 150 \\
\hline Overall Ranking & $\mathrm{R}$ & 162 & 56 & 110 \\
\cline { 2 - 5 } & $\begin{array}{l}\text { Final } \\
\text { rank }\end{array}$ & 3 & 1 & 2 \\
\hline
\end{tabular}

Based on the evaluation comparison data given in Table 4, it may be noted that:

a) None of the soil improvement techniques proved to perform consistently with respect to the evaluation criteria set in this analysis. Significant overall performance differences were indicated by various methods. The overall ranking indices $(\mathrm{R})$ values ranged from 56 for the method ranked as the best (sand drains) to 162 for the staged construction rated as of the poorest performance with an intermediate ranking index of 110 for the sand compaction piles method. Thus, the sand drain method is considered to be of the highest overall performance followed by the sand compaction piles whereas staged construction techniques is rated as of the lowest overall performance.

b) If the degree of improvements related to the settlement and shear strength properties of the treated foundation soils is the governing embankment design criteria, then the sand drain method will also come first followed by the staged construction and sand compaction piles methods in the second and third places respectively.

c) In case the embankment construction time will be the sole decisive factor, as was the actual situation for this project, then the SCP technique would be the preferred soil improvement technique followed by the sand drain and the staged construction as the second and third methods respectively.

d) On the other hand, if there are constraints on the budget allocated for project finance, then the staged construction method is considered as the most economical soil improvement design for this project. The sand drain or sand compaction pile methods may be adopted if more funds could be secured before commencement of construction works.

\section{Conclusions}

This study investigates the suitability of staged construction, sand drains and sand compaction piles soil improvement methods for the design of a $12 \mathrm{~m}$ high earth embankment on weak and compressible alluvial clay deposits 
Based on the subsurface soil conditions at study site, either of the following design options may be used to improve the characteristics of highly compressible embankment foundation soils:

(i) To build the embankment in three construction stages with 6 months waiting time after first and second stages, or

(ii) To install vertical sand drains of $0.2 \mathrm{~m}$ diameter spaced at $2.8 \mathrm{~m}$ in triangular grid pattern through the upper soft clay soils and extended down to pervious strata, or

(iii) To use $1.0 \mathrm{~m}$ diameter sand compaction piles arranged at $2.0 \mathrm{~m}$ spacing in a triangular grid pattern.

The study results showed that the above design options produced satisfactory improvements in treated foundation soils with respect to stability and the future performance of embankment.

An evaluation of the above techniques was made with respect to their expected performances when applied for embankment construction at the study site. The evaluation was based on the degree of soil improvement achieved by each method; the time required for construction and rough comparisons of estimated improvement costs. Depending on the most critical and/or decisive design/construction factor the most appropriate soil improvement technique may be adopted as discussed in this paper.

For the case study under consideration, the sand drain ground improvement method is considered to be the most appropriate based on the overall performance followed by the sand compaction piles technique whereas the staged construction method was rated in the third place.

\section{References}

1. "Guidelines on soft soils - Stage construction method," Guideline No. GE: G-5, Geotechnical Engineering Directorate, Research Design and Standards Organisation, Ministry of Railway, Manak Nagar, India (2005)

2. G. Sanglerat, G. Olivari and B. Cambou, "Practical problems in soil mechanics and foundation engineering, 1", Elsevier, Amsterdam (1985)

3. R. A. Barron, "Consolidation of fine grained soils by drain wells", TRANSACTIONS, ASCE, Vol. 113, p718 (1948)

4. S. M. H. Kirmani, "Consolidation of soil for foundation by using sand drains" IEP-SAC Journal, Riyadh, Saudi Arabia (2004-2005)

5. M. Kitazume, "The sand compaction pile method" Taylor and Francis Publishers, 246p, (2005) 